\title{
"The influence of corporate governance on the intellectual capital disclosure: a study on Indonesian private banks"
}

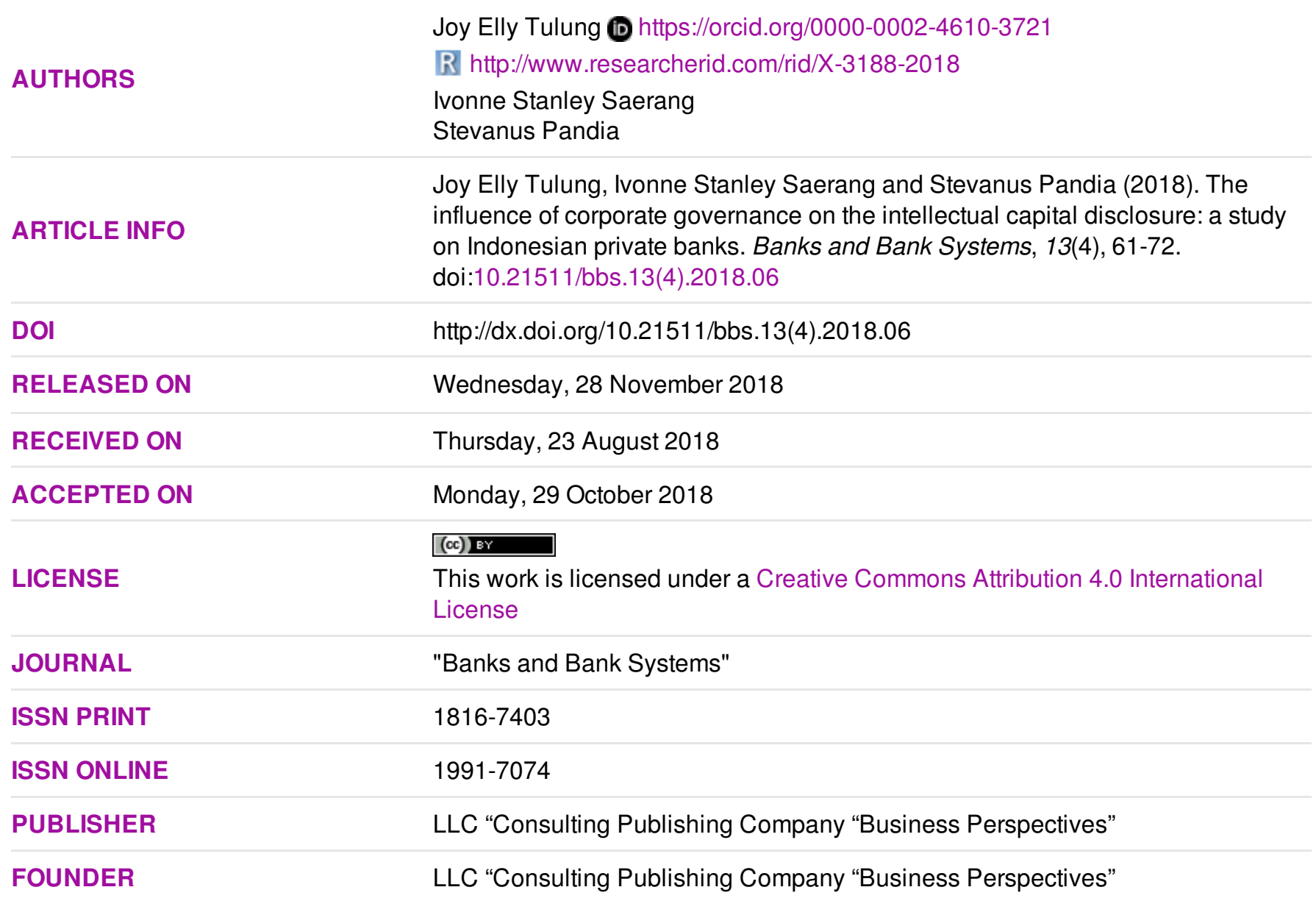

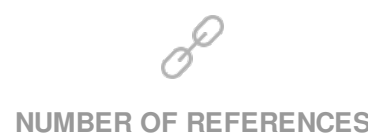

38
NUMBER OF FIGURES

1
NUMBER OF TABLES

4

(C) The author(s) 2023. This publication is an open access article. 


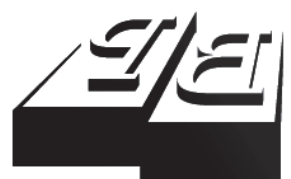

BUSINESS PERSPECTIVES

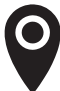

LLC "CPC "Business Perspectives" Hryhorii Skovoroda lane, 10, Sumy, 40022, Ukraine

www.businessperspectives.org

Received on: $23^{\text {rd }}$ of August, 2018 Accepted on: $29^{\text {th }}$ of October, 2018

(C) Joy Elly Tulung, Ivonne Stanley Saerang, Stevanus Pandia, 2018

Joy Elly Tulung, Ph.D., Department of Management, Sam Ratulangi

University, Indonesia.

Ivonne Stanley Saerang, Dr. Department of Management, Sam Ratulangi University, Indonesia.

Stevanus Pandia, Sam Ratulangi University, Indonesia.
Joy Elly Tulung (Indonesia), Ivonne Stanley Saerang (Indonesia),

Stevanus Pandia (Indonesia)

\section{THE INFLUENCE}

OF CORPORATE GOVERNANCE

ON THE INTELLECTUAL

CAPITAL DISCLOSURE:

\section{A STUDY ON INDONESIAN PRIVATE BANKS}

\begin{abstract}
The release of bank's intellectual capital is one of the important elements of bank's annual reports. Although it is not presented adequately in the annual reports, voluntary disclosure of bank's intellectual capital relatively represents the response to the needs of greater information for the users. This research aims to see the influence of corporate governance on the intellectual capital disclosure based on a case study on private banks in Indonesia. The variables to be examined in the research include the Composition of Independent Commissioners as well as The Competence of Audit Committee and Risk Oversight Committee. The samples were taken using purposive sampling, considering particular criteria. As many as 62 banks are selected to be taken as research samples. The data were analyzed using multiple linear regression analysis method. The result of a partial test shows that the Composition of Independent Commissioners has a positive and significant influence on the intellectual capital disclosure; the Competence of Audit Committee has a positive and significant influence on the intellectual capital disclosure; and the Competence of Risk Oversight Committee does not influence the intellectual capital disclosure. Meanwhile, the result of a simultaneous test shows that the Composition of Independent Commissioners, the Competence of Audit Committee, and the Competence of Risk Oversight Committee significantly influence the intellectual capital disclosure.
\end{abstract}

Keywords

JEL Classification
Indonesian banking, corporate governance, intellectual capital disclosure, Indonesia

\section{INTRODUCTION}

A company's main goal is to maximize the profits for the shareholders. However, the company also has the obligation to contribute to the community in general. To accommodate the company's obligation, a system called Corporate Governance can be implemented. In Indonesia, according to the Law No. 40 of 2004 regarding Limited Liability Company, the company is required to report its corporate governance to the public. Such obligation leads the company to disclose more information, as disclosure and transparency are the cores of corporate governance. This is understood as Intellectual Capital Disclosure.

Intellectual Capital Disclosure is one of the elements of voluntary disclosure. Although it is considered insignificant in an annual report, it has enough capacity to respond to the users' needs for greater in- 
formation. Although the Government has issued the regulation on the implementation of intellectual capital disclosure as stated in International Accounting Standard (IAS) 38 or Article 19 of Indonesian Financial Accounting Standard (PSAK in Indonesian), the shareholders are not fully aware of the potential of intellectual capital. It is evident in the low number of companies listed on the Indonesia Stock Exchange, particularly banks, performing Intellectual Capital Disclosure.

Research on the practices of Intellectual Capital Disclosure in the annual reports of public companies in Indonesian context is interesting to conduct (Purnomosidhi, 2005). First, it is because of the unavailability of standards on the items included in the intangible assets to be managed, measured, and disclosed, either through mandatory disclosure or through voluntary disclosure. Second, it is to look for detailed information in the management of intellectual capital, ranging from summary, measurement, to disclosure in the financial statements of the company. Third, the business sector in Indonesia lacks competitive excellence, leading to the low competitiveness and lack of ability to keep the company's survival.

Singh and Zahn (2008) used an index to measure Intellectual Capital Disclosure, which is based on the similarity of research objects. The index consists of 81 items classified into six categories: resources ( 28 items), customers (14 items), information technology (6 items), processes ( 9 items), research and development (9 items) and strategic statements (15 items). The index of ICD is adapted from Beaulieu et al. (2002), Bukh et al. (2005a) and Williams (2001).

Based on the research conducted by Uzliawati (2015), the rate of Intellectual capital disclosure reached the percentage of $52 \%$. It was higher than the result of previous research by Suhardjanto and Wardhani (2010), which was 34\%. The increase shows that banking has become aware of the importance of intellectual capital disclosure. Corporate governance is one of the factors influencing intellectual capital disclosure, for one of the principles is to prevent any fraud of the internal part of the company, particularly banking. Intellectual capital disclosure in a company is one of the implications of the implementation of good corporation governance, stating that company is required to consider the stakeholder interests in order to avoid information asymmetry between the internal party and the stakeholder.

In this study, Corporate Governance is selected as one of the factors influencing Intellectual Capital Disclosure. It is one of the monitoring tools to prevent fraud in the internal parties of the companies, especially banking, in using and disclosing the intellectual capital. Intellectual Capital Disclosure of the company is one of the implications of the implementation of good corporate governance stating that companies are required to consider the stakeholders' interests to prevent asymmetric information between internal parties and the stakeholders. The company's decision makers have fiduciary duty to take the full advantage of the intellectual capital, not only of the financial and physical capitals.

The Composition of Independent Commissioners, the Competence of Audit Committee, and the Competence of Risk Oversight Committee are treated as the indicators to proxy the variables of Corporate Governance as mentioned in the copy of the Regulation of Financial Services Authority No. 55/POJK03/2016 on the implementation of commercial banks governance. Besides, Corporate Governance is a range of relations between the company management, board, shareholders, and other parties having their interests in the company. Hence, it is known as the indicators included in the board of the corporate governance.

The study is necessary to be conducted in the Indonesian context because there has not been established a standardized guideline to measure the Intellectual Capital Disclosure and has not been implemented by the banks in Indonesia for its newness. The aims of the study are to find out the in- 
fluence of the Composition of Independent Commissioners, the Competence of Audit Committee, and the Competence of Risk Oversight Committee on the Intellectual Capital Disclosure, and the influence of those three indicators on the Intellectual Capital Disclosure simultaneously.

National private banks are taken as the object of this research. Financial sector is an ideal object for the research. A financial sector company, particularly banking, takes more advantage from its intellectual resources, compared to other sectors. However, businesses in banking, especially those dealing with a large sum of funds, are prone to fraud.

The research is interesting to carry out in the context of Indonesia because there has not been a standardized guideline to measure intellectual capital disclosure. Besides, not many researches have been conducted on this subject. Based on the background, the researcher will answer the question of "Do the Composition of Independent Commissioners, Audit Committee Competence, and Monitoring Committee Competence influence Intellectual Capital Disclosure?"

\section{LITERATURE REVIEW}

\subsection{Intellectual Capital Disclosure}

Klein and Prusak (1994) consider intellectual capital as "intellectual material that has been formalized, captured, and leveraged to produce a higher valued asset". To date, no single theory can explain the phenomena of complete disclosure (Leventis \& Weetman, 2004). However, several theories can serve as the base of it. Most researchers divide intellectual capital into three main elements: human capital, structural capital or organizational capital, and relational capital (Sveiby, 1997; Stewart, 2001; Meritum, 2002; Rodrigues et al., 2008). Most literatures on ICD in various countries focus more on the disclosure of ICD in their company annual report (Guthrie \& Petty, 2000). Mouritsen et al. (2001) stated that Intellectual Capital Disclosure in a financial statement is one of the ways to prove that the statement describes the credible and integrated activities of the company. They refer to the report of ICD, showing that many literatures on ICS are based on textual analysis of the statement. Further, Mouritsen et al. (2001) stated that Intellectual Capital Disclosure can be used by external and internal stakeholders by combining the reports in the forms of numbers, visualization, and narrative with the purpose of creating values. The research was supported by Buck et al. (2001), stating that the ICD report, in the practice, contains various information, both financial and non-financial, such as the cycle of customer satisfaction, employees, job satisfaction, supplies, etc.

\subsection{Corporate Governance}

Ho and Wong (2001) stated that Corporate Governance is seen as an effective means to illustrate the rights and responsibilities of each group of stakeholders in a company, where transparency becomes the main indicator of the corporate governance standards in the economy. Cadburry Report first introduced the term 'Corporate Governance' in 1992. The Cadburry Report is the starting point of the corporate governance around the globe. The Cadburry Committee considers three main matters: Board of Directors (BoD), Audit, and Shareholders. Cadburry Report states, "Corporate governance is a number of activities shaping the internal regulation of the enterprise in accomplishing their duties in the company, which is in accordance with the laws, ownership, and control. It covers trust asset, management, and distribution". Forum for Corporate Governance in Indonesia (FCGI) suggests that in Indonesia, corporate governance is defined as "a set of rules regulating the relations between the stakeholders, a committee, a creditor, a government, employees, as well as internal and external stakeholders". Uwigbe et al. (2018) investigated the Corporate Governance of a bank listed on the Nigerian Stock Exchange 2008-2015. They found there is no relationship between corporate governance such as board size and board independence and timeliness of financial report. Therefore, 
Braendle (2018) found that a weak corporate governance in European Banking Union on financial institutions has been a contributing factor of the financial crisis.

\subsection{Composition of Independent Commissioners}

The Regulation of the Financial Services Authority No. 55/POJK.03/2016, Part I, Article 1, Paragraph (4) states: "Independent Commissioner is the member of Board of Commissioners, that is not related to the financial, committee, share ownership, and/or the family of members of directors, members of other Boards of Commissioners, and/or controlling shareholders, or to the bank that may affect its capability in performing independently. Board of Commissioners is a form of internal control mechanism in making the decision to ensure the suitability of management behavior with the expectation of the company owner. Independent Commissioner means the member of a Board of Commissioners who has no affiliation to the directors, members of other Boards of Commissioners, and controlling shareholders and who is independent from business relation or other relations that may affect their ability to act independently". Haniffa and Cooke (2005) stated that the higher the number of independent commissioners in the board, the more they play their role in the wider disclosure in the purpose of creating relevant value of intellectual capital for the stakeholders. Savitri (2016) found that independent commissioners together with institutional ownership and public accounting correlate with the integrity on the financial statement. Therefore, Nasir and Abdullah (2004) concluded in their research that there is a positive significant correlation between independent commissioners and a disclosure. The empiric fact found that independent commissioners are positively correlated to the disclosure of internal structure/internal capital (Cerbioni \& Parbonetti, 2007). Li et al. (2008) also found positive significant correlation between independent commissioners and intellectual capital disclosure.

\section{H1: The Composition of Independent Commissioners significantly influences Intellectual Capital Disclosure.}

\subsection{Competence of Audit and Risk Oversight Committees}

The Regulation of Financial Services Authority No. 55/POJK.03/2016 Part IV, Article 41, explains that there are two independet parties in Audit Committee: accounting or finance and banking or law experts. As for the Risk Oversight Committee, there should be independent party that consists of professionals in risk management. Savitri (2016) found that "independency has no moderating effect on the relationship between managerial ownership and the Audit Committee in the integrity of financial statements". Audit Committee is a board of an operational committee responsible for monitoring the financial statements and disclosure. Effective audit committee should improve internal control and act to decrease the agency cost. Besides, it serves as strong controlling tool to improve intellectual capital disclosure valuable for the company. The existence of an audit committee relates to reliable financial statement, to quality improvement, and to disclosure (Ho \& Wong, 2001).

\section{H2: The Competence of the Audit Committee significantly influences Intellectual Capital Disclosure.}

Disclosure of the company risk-management is one of the elements in the information of a company's non-financial statements. Based on ERM framework published by COSO, there are 108 items of ERM disclosure that include eight dimensions: 1) internal environment; 2) event identification; 3) goal setting; 4) assessment of the risk; 5) response to risk; 6) communication and information; 7) supervising activities; and 8) monitoring (Desender, 2007). All the components are necessary in achieving the company's goals, which consist of strategic goals, operational goals, financial statements and obedience to regulations.

H3: It is assumed that the Competence of the Risk Oversight Committee significantly influences Intellectual Capital Discourse.

\section{METHODS}

The research belongs to associative types, which aim to see the correlation or the influence among variables in the research. 


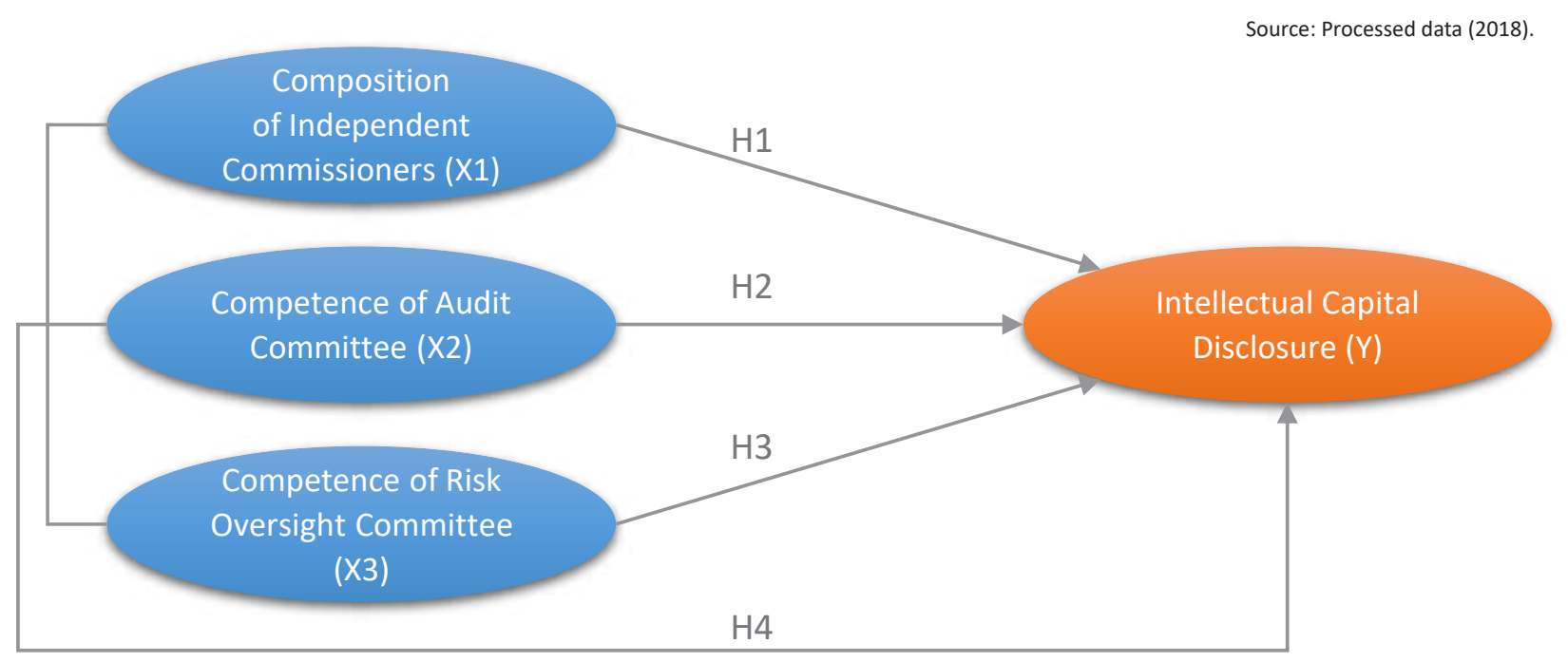

Figure 1. Conceptual framework

\subsection{Population, sample and sampling technique}

The population of this research includes national private banks listed in the Financial Services Authority, which consists of 75 banks. The samples are part of the population treated as the object of the research. In this research, the samples are selected using purposive sampling methods with the following criteria:

1) having published an annual report of 2012-2016; and

2) completing the financial data.

Based on the criteria, 62 banks were selected to be used as the samples. The research focuses on the data provided in the annual reports of the national private banks obtained from the official websites of each bank.

\subsection{Data and source of the data}

\subsubsection{Data types}

Data are a set of information necessary to make a decision. Kuncoro $(2009$, p. 145) suggests several kinds of data:

1) quantitative data, which are measured using numerical unit (number); and
2) qualitative data, which cannot be measured using numerical scale.

The data used in this research were quantitative in the forms of financial statements and annual reports issued by national private banks.

\subsubsection{Data source}

Kuncoro (2009, p. 145) states that data sources can be classified into:

1) primary data, which are obtained through field survey using all methods of ordinal data collecting; and

2) secondary data, which are obtained in data collecting and published to the users.

In this research, the data used are of secondary type. The data source includes the publication in the forms of annual reports and financial statements of the national private banks published on the official websites of each bank.

\subsubsection{Data collecting technique}

The research data were collected using documentation methods, collecting and analyzing the data and the necessary documents. They are in the forms of annual reports and financial statements 


\begin{tabular}{|c|c|c|c|c|}
\hline Varible & Definition & Indicator & Formulation/Proxy & Scale \\
\hline \multicolumn{5}{|c|}{ Dependent $(\mathrm{Y})$} \\
\hline 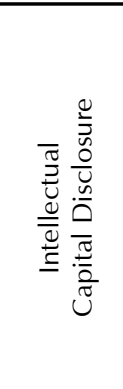 & $\begin{array}{l}\text { In Widarjo (2011), it is known that intellectual capital disclosure is } \\
\text { proxied using disclosure index. The index used in this research is from } \\
\text { Singh and Zahn (2008). It is based on the similarities of research objects, } \\
\text { those are companies carrying out IPO. The disclosure item of this index } \\
\text { is more comprehensive compared to that used by Buck et al. (2005) and } \\
\text { Abdolmohammadi (2005). } \\
\text { The data collecting method used to analyze the Intellectual Capital } \\
\text { Disclosure is the one used by Singh and Zahn (2008), Widarjo (2011), } \\
\text { Devi, Budiasih, and Badera (2017), namely content analysis. Unweight } \\
\text { dichotomous scale is used in scoring each item: } 1 \text { for the disclosed item } \\
\text { and } 0 \text { for the undisclosed item. The score of each item will be summed } \\
\text { up to obtain the total disclosure score for each company. }\end{array}$ & $\begin{array}{l}\text { 1. Resources ( } 28 \text { items) } \\
\text { 2. Customers ( } 14 \text { items) } \\
\text { 3. Information technology ( } 6 \text { items) } \\
\text { 4. Processes ( } 9 \text { items) } \\
\text { 5. Research and development }(9 \text { items) } \\
\text { 6. Strategic statements }(15 \text { items) } \\
\end{array}$ & $\begin{array}{c}\mathrm{ICD}=\frac{\sum_{i j} \text { DItem }}{\sum_{i j} \text { ADItem }} \\
\text { Keterangan: } \\
\text { ICD: Intellectual Capital Disclosure } \\
\sum_{i j} \text { DItem: Total Score Item ICD yang diungkapkan } \\
\sum_{i j} \text { ADItem }: \text { Total Item ICD yang seharusnya } \\
\text { diungkapkan }\end{array}$ & $\%$ \\
\hline \multicolumn{5}{|c|}{ Independent $(X)$} \\
\hline \multirow{2}{*}{ 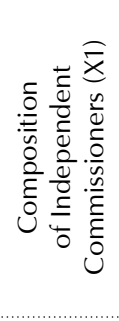 } & \multirow{2}{*}{$\begin{array}{l}\text { The Composition of Independent Commissioners is the members } \\
\text { of the Board of Commissioners who are not related to the financial, } \\
\text { committee, share ownership, and/or family of the members of the } \\
\text { Board of Directors, members of other Boards of Commissioners and/ } \\
\text { or controlling shareholders, or any relation to the bank that may affect } \\
\text { their ability to act independently. The Composition of the Independent } \\
\text { Commissioners can illustrate the level of independence and } \\
\text { objectiveness of the board in making the decision. The independence of } \\
\text { the Board of Commissioners is stated in the percentage of the members } \\
\text { of independent commissioners compared to the total number of the } \\
\text { members of the Board of Commissioners (Subramaniam et al., 2009). }\end{array}$} & & Number of Independent Commissioners & \multirow{2}{*}{$\%$} \\
\hline & & & Number of the total Board of Commisioners & \\
\hline \multirow{2}{*}{ 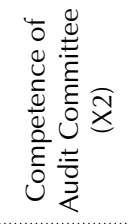 } & \multirow{2}{*}{$\begin{array}{l}\text { Audit Committee is the sub-committee of the board of directors } \\
\text { consisting of external independent directors (Tunggal 2013, p. 242). The } \\
\text { Audit Committee in this research includes the competence of the Audit } \\
\text { Committee assessed from the educational background and the expertise } \\
\text { of each member of the Committee in accordance with the Regulation } \\
\text { of Financial Services Authority No. 55/POJK.03/2016. Each competent } \\
\text { member will be scored 1, otherwise is } 0 \text {. }\end{array}$} & & Number of Competent Members & \multirow{2}{*}{$\%$} \\
\hline & & & Number of Audit Committee Members & \\
\hline \multirow{2}{*}{ 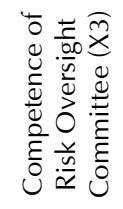 } & \multirow{2}{*}{$\begin{array}{l}\text { Risk Oversight Committee is a mechanism of monitoring the risk } \\
\text { necessary for the company (Subramaniam et al., 2009). In this research, } \\
\text { what is overlooked is the competence assessed from the educational } \\
\text { background and the expertise of each member of the Committee in } \\
\text { accordance with the Regulation of Financial Services Authority No. 55/ } \\
\text { POJK.03/2016. Each competent member will be scored 1, otherwise is } 0 .\end{array}$} & & Number of Competent Members & \multirow{2}{*}{$\%$} \\
\hline & & & Number of Audit Committee Members & \\
\hline
\end{tabular}


obtained from the official websites of each bank. Table 1 presents the operational definition of the variables used in the research.

\section{RESULTS}

\subsection{Variable description}

Descriptive statistic is used to provide statistic illustration of the independent and dependent variables of the research. The variables are the Composition of Independent Commissioners, the Competence of Audit Committee, the Competence of Risk Oversight Committee, and the Intellectual Capital Disclosure of 2012-2016, as shown in the description of the results. The information provided in the descriptive statistics is in the forms of mean, minimum score, maximum score, and standard deviation of each variable, which is presented in Table 2.

Table 2. Results of the descriptive statistic test

\begin{tabular}{|c|c|c|c|c|c|}
\hline \multicolumn{6}{|c|}{ Descriptive Statistics } \\
\hline Variables & $\mathbf{N}$ & Min & $\operatorname{Max}$ & Mean & $\begin{array}{c}\text { Std. } \\
\text { deviation }\end{array}$ \\
\hline $\begin{array}{l}\text { Composition } \\
\text { of Independent } \\
\text { Commissioners }\end{array}$ & 310 & 33 & 100 & 60.68 & 11.089 \\
\hline $\begin{array}{l}\text { Competence of } \\
\text { Audit Committee }\end{array}$ & 310 & .50 & 1.00 & .9859 & .07366 \\
\hline $\begin{array}{l}\text { Competence of } \\
\text { Risk Oversight } \\
\text { Committee }\end{array}$ & 310 & .75 & 1.00 & .9977 & .02300 \\
\hline $\begin{array}{l}\text { Intellectual } \\
\text { Capital } \\
\text { Disclosure }\end{array}$ & 310 & 16.05 & 50.62 & 34.9662 & 6.92190 \\
\hline Valid N (listwise) & 310 & & & & \\
\hline
\end{tabular}

Note: $\mathrm{N}$ - number of data; Min - variable smallest score; Max variable greatest score; Mean - variable mean.

\subsection{Composition of Independent Commissioners}

Based on the descriptive statistic test presented in Table 2, it is known that the minimum score of the Composition of Independent Commissioners is 33 and the maximum is 100 . Thus, the composition ranges from 33 to 100 with the mean of 60.68 and the standard deviation of 11.089. The mean is higher than the standard deviation, meaning that the score distribution of composition is good. The data is homogeneous where the gap between the minimum and the maximum scores of variable during the period of research is small.

\subsection{Competence of the Audit Committee}

Based on the descriptive statistics test (see Table 2 ), it is known that the minimum score of the Competence of the Audit Committee is 0.50 and the maximum is 1 . Thus, the composition ranges from 0.50 to 1 with the mean of 0.9859 and the standard deviation of 0.07366 . The mean is higher than the standard deviation, meaning that the distribution of the score of the competence is good. The data is homogeneous, where the gap between the minimum and the maximum scores of the variable during the period of the research is small.

\subsection{Competence of the Risk Oversight Committee}

Based on the descriptive statistics test presented in Table 2, it is known that the minimum score of the competence of the Risk Oversight Committee is 0.75 and the maximum is 1 . Thus, the composition ranges from 0.75 to 1 with the mean of 0.9977 and the standard deviation of 0.02300 . The mean is higher than the standard deviation, meaning that the distribution of the score of the competence is good. The data is homogeneous, where the gap between the minimum and the maximum scores of the variable during the period of the research is small.

\subsection{Intellectual Capital Disclosure}

Based on the descriptive statistics test presented in Table 2, it is known that the minimum score of the Intellectual Capital Disclosure is 16.05 and the maximum is 50.62 . Thus, the composition ranges from 16.05 to 50.62 with the mean of 34.9662 and the standard deviation of 6.92190 . The mean is higher than the standard deviation, meaning that the distribution of the score of the intellectual capital disclosure is good. The data is homogeneous, where the gap between the minimum and the maximum scores of the variable during the period of the research is small. 


\subsection{Result description}

All variables show tolerance $>0.1$ and the score of VIF $<10$. The tolerance coefficient of Independent Commissioners is 0.974 higher than 0.1 and the VIF of 1.027 is smaller than 10 (Table 3). Tolerance coefficient of the competence of the Risk Oversight Committee is 0.910 higher than 0.1 and VIF of 1.098 is smaller than 10 . It proves that multicollinearity does not occur to all independent variables of this research. Therefore, the regression model is appropriate to use in the research.

According to Table 3, the equations of multiple linear regression with the three independent variables are:

$$
\begin{aligned}
& Y=a- b_{-} 1 . X 1+b_{-} 2 . X 2-b_{-} 3 . X 3+e, \\
& Y=a-b_{-} 1 \text { KomposisiKI }+ \\
&+b_{-} 2 \text { KompetensiKA- } \\
&-b_{-} 3 \text { KompetensiKPR }+e, \\
& Y=49.609-0.119 \text { KomposisiKI }+ \\
&+13.596 \text { KompetensiKA- } \\
&-20.898 \text { KompetensiKPR }+e .
\end{aligned}
$$

The regression equation can be explained as follows:

1. The Constanta is 49.609 , meaning that if the Composition of Independent Commissioners (X1), Competence of Audit Committee (X2), and Competence of Risk Oversight Committee (X3) are zero, the independent score of the Intellectual Capital Disclosure is 49.609.

2. The coefficient of the Composition of Independent Commissioners (X1) is -0.119 . It means that if another independent variable is unchanged and the Composition of Independent Commissioners (X1) increases by 1 point or by $1 \%$, the Intellectual Capital Disclosure $(Y)$ will decrease as much as 0.119 . The coefficient is negative, meaning that there is a negative correlation between $X 1$ and $Y$. The higher the $X 1$, the lower the $Y$.

3. The coefficient of the Competence of Audit Committee $(X 2)$ is 13.596. It means that if another independent variable is unchanged and the Competence of Audit Committee (X2) increases by 1 point or $1 \%$, the Intellectual Capital Disclosure $(Y)$ will increase as much as 13.596. The coefficient is positive, meaning that there is a positive correlation between $X 2$ and $Y$. The higher the $X 1$, the higher the $Y$.

The coefficient of the Competence of Risk Oversight Committee (X3) is -20.896 . It means that if other independent variable is unchanged and the Competence of Risk Oversight Committee (X3) increases by 1 point or $1 \%$, the Intellectual Capital Disclosure $(Y)$ will increase as much as 20.896 .

\begin{tabular}{|c|c|c|c|c|c|c|c|c|c|c|}
\hline \multicolumn{11}{|c|}{ Coefficients $^{a}$} \\
\hline \multirow{2}{*}{ Model } & \multicolumn{2}{|c|}{$\begin{array}{l}\text { Unstandardized } \\
\text { coefficients }\end{array}$} & \multirow{2}{*}{$\frac{\begin{array}{c}\text { Standardized } \\
\text { coefficients }\end{array}}{\text { Beta }}$} & \multirow{2}{*}{$\mathbf{t}$} & \multirow{2}{*}{ Sig. } & \multicolumn{3}{|c|}{ Correlations } & \multicolumn{2}{|c|}{$\begin{array}{l}\text { Collinearity } \\
\text { statistics }\end{array}$} \\
\hline & B & $\begin{array}{l}\text { Std. } \\
\text { error }\end{array}$ & & & & $\begin{array}{l}\text { Zero- } \\
\text { order }\end{array}$ & Partial & Part & Tolerance & VIF \\
\hline Constant & 49.609 & 17.163 & & 2.891 & .004 & & & & & \\
\hline $\begin{array}{l}\text { Composition } \\
\text { of Independent } \\
\text { Commissioners }\end{array}$ & -.119 & .035 & -.190 & -3.362 & .001 & -.169 & -.189 & -.187 & .974 & 1.027 \\
\hline $\begin{array}{l}\text { Competence } \\
\text { of Audit Committee }\end{array}$ & 13.596 & 5.495 & .145 & 2.474 & .014 & .107 & .140 & .138 & .910 & 1.099 \\
\hline $\begin{array}{l}\text { Competence } \\
\text { of Risk Oversight } \\
\text { Committee }\end{array}$ & -20.898 & 17.591 & -.069 & -1.188 & .236 & -.012 & -.068 & -.066 & .910 & 1.098 \\
\hline
\end{tabular}
The coefficient is negative, meaning that there is a negative correlation between $X 3$ and $Y$. The higher the $X 1$, the lower the $Y$.

Table 3. Multicollinearity statistics test results, multiple linear regression test results, and T-test statistic results.

Source: Processed data of the research result (2018).

Note: ${ }^{a}$ means dependent variable: Intellectual Capital Disclosure. 


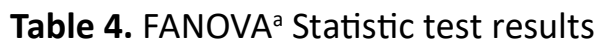

Source: Processed data of the research result (2018).

\begin{tabular}{c|c|c|c|c|c}
\hline Model & $\begin{array}{c}\text { Sum of } \\
\text { squares }\end{array}$ & Df & $\begin{array}{c}\text { Mean } \\
\text { square }\end{array}$ & F & Sig. \\
\hline Regression & 715.515 & 3 & 238.505 & 5.180 & $.002^{\mathrm{b}}$ \\
\hdashline Residual & 14089.526 & 306 & 46.044 & & \\
\hline Total & 14805.041 & 309 & & & \\
\hline
\end{tabular}

Note: ${ }^{a}$ - dependent variable: Intellectual Capital Disclosure; b - predictors: (Constant), Competence of Risk Oversight Committee, Composition of Independent Commissioners, Competence of Audit Committee.

As shown in Table 4, F-value is 5.180, with significance probability of 0.02 . The value is lower than 0.05 . In accordance with the base of decision making in F-test, the simultaneous variables of Independent Commissioners Composition (X1), the Competence of Audit Committee (X2), and the Competence of Risk Oversight Committee (X3) significantly influence Intellectual Capital Disclosure $(Y)$.

\subsection{T-test statistic (significance test of individual parameters)}

T-test is conducted to know the influence of Composition of Independent Commissioners (X1), the Competence of Audit Committee (X2), and Competence of Risk Oversight Committee (X3) on the Intellectual Capital Disclosure $(Y)$ in partial. The hypothesis of partial test is made with the following criteria:

1. If the significance level is above $5 \%, \mathrm{HO}$ is accepted and $\mathrm{Ha}$ is rejected.

2. If the significance level is below $5 \%, \mathrm{HO}$ is rejected and $\mathrm{Ha}$ is accepted.

As indicated in Table 3, the significance level of regression coefficient value of the Composition of Independent Commissioners is 0.001. It is below 0.05 or sig value $<\alpha$. Other than probability value or sig value, other method to use is t-value of calculation compared to the $t$-value of the table. In this case, $\mathrm{t}$-count is -3.362 , while the $\mathrm{t}$-table is 1.97214 , it means $\mathrm{t}$-count $>\mathrm{t}$-table. Thus, $\mathrm{HO}$ is rejected and $H 1$ is accepted. In other words, the Composition of Independent Commissioners has negative and significant influence on the Intellectual Capital Disclosure.
As shown in Table 3, the significance level of regression coefficient value of the Competence of Audit Committee is 0.014 . It is below 0.05 or sig value < a. Other than probability value or sig value, other method to use is t-value of calculation compared to the $\mathrm{t}$-value of the table. In this case, $\mathrm{t}$-count is 2.474 , while the $\mathrm{t}$-table is 1.97214 . It means $\mathrm{t}$-count $>\mathrm{t}$-table. Thus, $\mathrm{HO}$ is rejected and $\mathrm{Hl}$ is accepted. In other words, the Competence of Audit Committee significantly influences the Intellectual Capital Disclosure.

Based on Table 3, it is also known that the significance level of the regression coefficient value of the Competence of Risk Oversight Committee is 0.236 . It is above 0.05 or sig value $>\alpha$. Other than probability value or sig value, other method to use is t-value of calculation compared to the $\mathrm{t}$-value of the table. In this case, $\mathrm{t}$-count is -1.188 , while the $\mathrm{t}$-table is 1.97214 . It means $\mathrm{t}$-count < $\mathrm{t}$-table. Thus, $\mathrm{HO}$ is accepted and $\mathrm{H} 1$ is rejected. In other words, the Competence of Risk Oversight Committee does not have any significant influence on the Intellectual Capital Disclosure.

\subsection{Factors influencing the Intellectual Capital Disclosure}

\subsubsection{Composition of Independent Commissioners}

Table 3 shows that $\mathrm{t}$-count is -3.362 and the significance value is 0.001 at the significance level of 0.05 . It can be concluded that $0.001<0.05$, where the hypothesis (H1) is accepted. Partially, the Composition of Independent Commissioners negatively and significantly influences the Intellectual Capital Disclosure.

The results are consistent with the research conducted by Nurfauzi and Santoso (2015), concluding that the Proportion of Independent Commissioners significantly influences the Intellectual Capital Disclosure. The research by $\mathrm{Li}$ et al. (2008) also shows that the proportion significantly influences the Intellectual Capital Disclosure.

Besides, the research's negative result shows that the number of independent commissioners in the board of commissioners increases. Therefore, the Intellectual Capital Disclosure conducted by a bank or a certain company will decrease. 


\subsection{Competence of Audit Committee}

Based on Table 3, the t-count is 2.474 and the significance value is 0.014 at the significance level of 0.05 . It can be concluded that $0.014<0.05$, where hypothesis (H2) is accepted. The research shows that, partially, the Competence of Audit Committee has a positive and significant influence on the Intellectual Capital Disclosure.

The result is consistent with the research conducted by Nurfauzi and Santoso (2015), stating that the higher the Audit Committee, the higher the level of Intellectual Capital Disclosure. Masita et al. (2017) also found that the size of the Audit Committee has a significant and positive influence on the Intellectual Capital Disclosure. Here, the size is correlated to the Competence of Audit Committee, meaning that the competence is used to measure the Committee. Therefore, the Competence of Audit Committee members will influence the Intellectual Capital Disclosure of the bank or a certain company.

\subsection{Competence of Risk Oversight Committee}

Based on Table 3, t-count is -1.188 and the significance value is 0.236 at the significance level of 0.05 . To conclude, $0.235>0.05$, meaning that hypothesis $H 3$ is rejected. The results show that, partially, the Competence of Risk Oversight Committee is negative and is not significant to the Intellectual Capital Disclosure.

The result is different from the research conducted by Nurfauzi and Santoso (2015), suggesting that the bigger the size of the Audit Committee, the higher the level of the Intellectual Capital Disclosure. The research by Masita et al. (2017) also found that the size of the Committee significantly and positively influences the Disclosure.
Since no literature was found about the Risk Oversight Committee, the reference on Audit Committee is used because basically they are similar. The result is also related to the research by Restuningdiah (2011), concluding that the Risk Oversight Committee does not influence the Profit Management.

Another research, conducted by Sutikno et al. (2014), also stated that the company size significantly influences the Profit Management. In this case, the committee is different from the size. Meanwhile, a research by Utomo and Chariri (2015) found that the size of a company influences the Intellectual Capital Disclosure. Therefore, the result of the present research is against other variable, which is the size of the company. In short, the competence of the members does not influence the Intellectual Capital Disclosure of the bank or a certain company.

\subsection{Composition of independent commisioners, competence of Audit Committee, and Competence of Risk Oversight Committee (simultaneously)}

Based on Table 4, F-count is 5.180 with the significance probability of 0.02 . It is evident that the score is below 0.05. In accordance with the consideration of decision making in F-test, the Composition of Independent Commissioners (X1), Competence of Audit Committee (X2), and Competence of Risk Oversight Committee (X3) simultaneously and significantly influence the Intellectual Capital Disclosure. Therefore, the number of Independent Commissioners, the Competence of Audit Committee Members, and the Competence of Risk Oversight Committee Members simultaneously influence the Intellectual Capital Disclosure of a bank or a certain company.

\section{CONCLUSION}

Based on the hypothesis test and the above discussion, it can be concluded that the Composition of Independent Commissioners (X1) negatively and significantly influences the Intellectual Capital Disclosure of national private banks in 2016. The research shows that the increasing number of Independent Commissioner Members will decrease the Disclosure. The Competence of Audit 
Committee (X2) significantly influences the Intellectual Capital Disclosure of national private banks in 2016. The results show that the Competence of Audit Committee Members influences the Intellectual Capital Disclosure of national private banks.

The Competence of Risk Oversight Committee (X3) does not significantly influence the Intellectual Capital Disclosure of national private banks in 2016. It shows that the Competence does not influence the Disclosure. Simultaneously, the Composition of Independent Commissioners (X1), the Competence of Audit Committee (X2), and the Competence of Risk Oversight Committee (X3) influence the Intellectual Capital Disclosure of national private banks in 2016. Based on the study result, it is suggested that:

1. National private banks are expected to focus more on the Intellectual Capital Disclosure in their annual reports, thereby completing the Intellectual Capital in accordance with the available items.

2. Further studies need to be conducted in order to improve the limitation of this research and to develop the research using other factors or other independent variables apart from this research that may influence the Intellectual Capital Disclosure.

\section{REFERENCES}

1. Abdolmohammadi, M. J. (2005). Intellectual Capital Disclosure and Market Capitalization. Journal of Intellectual Capital, 6(3), 397-416. https://doi. org/10.1108/14691930510611139

2. Beaulieu, P. R., Williams, S. M., \& Wright, M. E. (2002). Intellectual Capital Disclosures in Swedish Annual Reports. In N. Bontis (Ed.), World Congress on Intellectual Capital Readings (pp.135-156). Hamilton: Butterworth-Heinemann. https://doi.org/10.1016/B978-07506-7475-1.50012-9

3. Braendle, U. (2018). The impact of the European Banking Union's Single Supervisory Mechanism on corporate governance practices in European banks. Banks and Bank Systems, 13(2), 164-177. https://doi. org/10.21511/bbs.13(2).2018.14

4. Bukh, P. N., Johansen, M. R., \& Mouritsen, J. (2001). Constructing intellectual capital statements. Scandinavian Journal of Management, 17(1), 87-108. https://doi.org/10.1016/S09565221(00)00034-8

5. Bukh, P. N., Nielsen, C., Gormsen P., \& Mouritsen, J. (2005). Disclosure of Information on Intellectual Capital in Danish IPO Prospectus. Accounting,
Auditing \& Accountability Journal, 18(6), 713-732. https://doi. org/10.1108/09513570510627685

6. Caesari, A. P., Abdul, K. I., \& Muhammad, S. (2015). Analisis Pengaruh Corporate Governance, Corporate Social Responsibility, Dan Corporate Financial Performance Perusahaan Indeks Kompas100. Jurnal Keuangan dan Perbankan. 19(3), 409-417. http://dx.doi.org/10.18202/ jam23026332.14.1.09

7. Cerbioni, F., \& Parbonetti, A. (2007). Exploring the Effects of Corporate Governance on Intellectual Capital Disclosure: An Analysis of European Biotechnology Companies. European Accounting Review, 16(4), 791-826. https://doi. org/10.1080/09638180701707011

8. Desender, K. A. (2007). On the Determinants of Enterprise Risk Management Implementation (Working paper). Retrieved from https://papers.ssrn.com/sol3/papers. cfm?abstract_id $=1025982$

9. Devi, S., Budiasih, I. G. N., \& Badera, I. D. N. (2017). Pengaruh Pengungkapan Enterprise Risk Management dan Pengungkapan Intellectual Capital Terhadap Nilai Perusahaan. Jurnal akuntansi dan keuangan Indonesia, 14(1),
20-45. http://dx.doi.org/10.21002/ jaki.2017.02

10. Guthrie, J., \& Petty, R. (2000). Intellectual capital: Australian annual reporting practices. Journal of intellectual capital, 1(3), 241-251. https://doi. org/10.1108/14691930010350800

11. Haniffa, R. M. \& Cooke, T. E. (2005). The Impact of Culture and Governance on Corporate Social Reporting. Journal of Accounting and Public Policy, 24(5), 391-430. https://doi.org/10.1016/j.jaccpubpol.2005.06.001

12. Ho, S. S. M., \& Wong, S. K. (2001). A Study of the Relationship between Corporate Governance Structures and the Extent of Voluntary Disclosure. Journal of International Accounting, Auditing and Taxation, 10(2), 139-156. https://doi. org/10.1016/s1061-9518(01)000416

13. Klein, D. A., \& Prusak, L. (1994). Characterising Intellectual Capital. Cambridge, MA: Centre for Business Innovation, Ernst and Young.

14. Kuncoro. (2009). Metode Riset Untuk Bisnis and Ekonomi. UPPAMP YKPN, Yogyakarta.

15. Leventis, S., \& Weetman, P. (2004). Timeliness of financial information 
disclosed: applicability of disclosure theories in emerging capital market. Accounting and Business Research, 34(1), 43-56. https://doi.org/10.1080 /00014788.2004.9729950

16. Li, J., Pike, R., \& Haniffa, R. (2008). Intellectual Capital Disclosure and Corporate Governance Structure in UK Firms. Accounting and Business Research, 38(2), 137-159. https:// doi.org/10.1080/00014788.2008.96 63326

17. Masita, M., Yuliandhari, W. S., \& Muslih, M. (2017). Pengatuh Karakteristik Komite Audit dann Kinerja Intellectual Capital Terhadap Pengungkapan Intellectual Capital. E-jurnal Akuntansi Universitas Udayana, 18(2), 1663-1715. Retrieved from https://ojs.unud.ac.id/index.php/ Akuntansi/article/view/28401

18. Meritum. (2002). Guidelines for Managing and Reporting on Intangibles. Madrid: Fundacio'n Airtel Mo'vil.

19. Mouritsen, J., Larsen, H. T., \& Bukh, P. N. (2001). Intellectual capital and the 'capable firm': narrating, visualizing and numbering for managing knowledge. Accounting organizations and society, 26(7-8), 735-762. https://doi.org/10.1016/ S0361-3682(01)00022-8

20. Nasir, M. N., \& Abdullah, S. N. (2004). Accrual Management and the roles of boards of directors and audit committees among Malaysian listed companies: Evidence during the Asian financial crisis. IIUM Journal of Management and economics, 12(1), 48-80. Retrieved from http://journals.iium.edu.my/ enmjournal/index.php/enmj/article/ view/97

21. Nurfauzi, Y., \& Santoso, A. L. (2015). Struktur corporate governance dan pengungkapan intellectual capital. Proceeding Seminar Nasional \& Call For Paper (SCA 5), 5(1). Retrieved from http://jp.feb.unsoed.ac.id/index.php/sca-1/article/view/591

22. Purnomosidhi, B. (2005). Analisis empiris terhadap diterminan praktik pengungkapan modal intelektual pada perusahaan publik di BEJ. Jurnal Riset Akuntansi Indonesia, 6(2), 118-119. Retrieved from: http://purnomo.lecture.ub.ac. id/files/2012/02/Diterminan-Modal-Intelektual.pdf
23. Restunigdiah, N. (2011). Komisaris Independen, Komite Audit, Internal Audit \& Risk Management Committee Terhadap Manajemen Laba. Jurnal Keuangan and Perbankan, 15(3), 351-362. Retrieved from http://jurnal.unmer. ac.id/index.php/jkdp/article/ view/1029/670

24. Rodrigues, L. M., Oliveira, L., \& Craig, R. (2008). Applying Voluntary Disclosure Theories to Intangibles Reporting: Evidence from the Portuguese Stock Market. http:// dx.doi.org/10.2139/ssrn.825764

25. Savitri, E. (2016). Corporate governance mechanism and the moderating effect of independency on the integrity of financial reporting. Investment Management and Financial Innovations, 4(13), 68-74. http://dx.doi.org/10.21511/ imfi.13(4).2016.06

26. Sing, I., \& Zahn, M. (2008). Determinants of intellectual capital disclosure in prospectuses of initial public offerings. Accounting and Business Research, 38(5), 409-431. https://doi.org/10.1080/00014788.2 008.9665774

27. Stewart, T. (2001). La Gestión del Concimiento y el Capital Intelectual. Buenos Aires: Granica.

28. Subramaniam, N., McManus, L., \& Zhang, J. (2009). Corporate Governance, Firm Characteristics, and Risk Management Committee in Australia Companies. Managerial Auditing Journal, 24(4), 316-319. http://dx.doi. org/10.1108/02686900910948170

29. Suhardjanto, D., \& Wardhani, M. (2010). Praktik intellectual capital disclosure perusahaan yang terdaftar di bursa efek Indonesia. Jurnal Akuntansi dan Auditing Indonesia, 14(1), 71-85. Retrieved from http://journal.uii.ac.id/JAAI/ article/view/2247

30. Sutikno, F., Wahidahwati, and Asyik, N F (2014). Pengaruh Corporate Governance dan Ukuran Perusahaan Terhadap Manajemen Laba di Industri Perbankan Indonesia. Jurnal Ilmu dan Riset Akuntansi, 3(10). Retrieved from https://core.ac.uk/download/ pdf/151521120.pdf
31. Sveiby, K. E. (1997). The New Organizational Wealth. USA: BerettKoehler Publishers.

32. Tulung, J. E., \& Ramdani, D. (2016). The Influence of Top Management Team Characteristics on BPD Performance. International Research Journal of Business Studies, 8(3), 155-166. https://doi.org/10.21632/ irjbs.8.3.155-166

33. Tunggal, A. W. (2013). Dasar-Dasar Pengendalian Internal dan Corporate Governance. Jakarta: Harvarindo.

34. Utomo, A., \& Chariri, A. (Eds.) (2015). Faktor-Faktor yang Mempengaruhi Pengungkapan Modal Intelektual dan Dampaknya Terhadap Nilai Perusahaan. Proceedings from Simposium Nasional Akuntansi XVII, Medan. Retrieved from http://lib.ibs.ac.id/ materi/Prosiding/SNA\%20XVIII/ makalah/024.pdf

35. Uwuigbe, U., Felix, E. D., Uwuigbe, O. R., Teddy, O., \& Irene, F. (2018). Corporate governance and quality of financial statements: a study of listed Nigerian banks. Banks and Bank Systems, 13(3), 1223. http://dx.doi.org/10.21511/ bbs.13(3).2018.02

36. Uzliawati, L. (2015). Dewan Komisaris dan Intellectual Capital Disclosure Pada Perbankan di Indonesia. Jurnal Keuangan dan Perbankan, 19(2), 226-234. Retrieved from http://jurnal.unmer. ac.id/index.php/jkdp/article/ view/845

37. Widiarjo, W. (2011). Pengaruh Modal Intelektual Dan Pengungkapan Modal Intelektual Pada Nilai Perusahaan Yang Melakukan Initial Public Offering. Jurnal Akuntansi dan Keuangan Indonesia Volume, 8(2), 157170. http://dx.doi.org/10.21002/ jaki.2011.10

38. Williams, M. S. (2001). Is intellectual capital performance and disclosure practices related? Journal of Intellectual Capital, 2(3), 192-203. http://dx.doi. org/10.1108/14691930110399932 